\title{
Shifting Identities in Modern Sindh: Bhil and Kohli Hindus of Khebar in the Shia Ismaili Muslim Community
}

\author{
Mahek Khwaja | ORCID: 0000-0003-1701-3089 \\ Independent Researcher, Karachi, Pakistan \\ mahekkhwajaı@gmail.com
}

\begin{abstract}
Indo-Muslim history is hybrid. The Hindu Bhil and Kohli communities of Khebar, Sindh, are examples of this hybridity. Before Partition in 1947, when socio-cultural ambivalence was widespread, Bhils and Kohlis lived alongside Muslims. After Partition, the situation changed, and these communities suffered socio-economic isolation. Between 1964 and 1979, Bhils and Kohlis in Kebhar experienced three waves of $d a^{\prime}$ wah (i.e., calling people to embrace Islam). In these waves, Ismaili missionaries targeted Patels (i.e., community headmen). In response, this group recognized the 49th Imam of Shia Ismaili Muslims as a manifestation of the dasa avatara from Hinduism. This article addresses what factors led to this recognition and how groups cross thresholds between Hinduism and Islam.
\end{abstract}

\section{Keywords}

Bhils - Kohlis - Khebar - Ismailis - conversion - Patel System - missionaries - Khebar Welfare Society

Sindh is a region historically rich in Ismaili missionary activity. Nizari Ismaili missionaries carried out da'wah missions in South Asia between the thirteenth

* I am especially thankful to the Ismaili Tariqah and Religious Education Board, Pakistan. I am also thankful to Alwaez Attash Sawja, Alwaez Madad Ali Karam Ali, and Alwaez Muhammad Yousuf for their support. I owe a special thanks to Dr. Michel Boivin and Dr. Matthew A. Cook for their comments and help with this article. 
and fifteenth centuries. ${ }^{1}$ The Khoja Ismaili community came into being because of these missions. ${ }^{2}$ In Conversions and Shifting Identities Ramdev Pir and the Ismailis in Rajasthan, Dominique-Sila Khan states that the term "Khoja" dates to the fifteenth century and Pir Sadardin, a Nizari Ismaili missionary who undertook a da'wah mission among Lohana. This group claimed to be martial caste Rajputs and adopted the "Thakur" title to symbolize their status. Pir Sadardin invented "equivalences between Hindu and Muslim concepts" to facilitate his mission and proposed the title of "Khwaja," an Islamic equivalent of Thakur. ${ }^{3}$ Khwaja means "Master" in Persian. It was a title given to nobles, merchants, and teachers. Khan posits that the title Khwaja (Khoja being its Gujarati and Sindhi pronunciation) does not ascribe a socio-economic status. Instead, it marks an achieved state that assumes socio-economic power. Individuals holding the Khwaja title could gain their position through wealth, genealogy, the virtue of service to a King, or by marriage.

Why were the Lohanas (and other groups) in Sindh open to the teachings of Nizari Ismaili missionaries like Pir Sadardin? While existing literature addresses questions about "when" and "how," there is little about "why." Nonetheless, Tazim Kassam, in Songs of Wisdom and Circles of Dance: Hymns of the Satpanth Ismaili Muslim Saint Pir Shams, does delve deeper into this question. ${ }^{4}$ Kassam points to atrocities inflicted in Sindh by Afghan and Turkish ghazis (i.e., warriors) and how they devastated temples, plundered royal coffers, and ill-treated women in the name of Islam. In defiance, the Sumrah Dynasty of Sindh (10261356) retained a Hindu culture that remained favorable to the Nizari Ismailis, who traced their ancestral history to the Fatimids of Persia. Alliance with the Nizari Ismailis was politically advantageous since they did not promote Islamization or Arabization and could accommodate regional cultural sensibilities in Sindh.

A comparison between the above history and the receptiveness of Bhils and Kohlis in Khebar to da'wah illuminates how these groups were open to the practices of Ismaili missionaries after Partition in 1947. Amin Valliani writes that, after Pakistan's independence, Ismailis like Bhagat Pirbhai (d. 1973) and Kassimali Badinwala (d. 1976) actively engaged in welfare development among

1 Dominique-Sila Khan, Conversions and Shifting Identities Ramdev Pir and the Ismailis in Rajasthan (New Delhi: Manohar, 1997), 39-44.

2 Ibid.

3 Ibid., 42.

4 Tazim Kassam, Songs of Wisdom and Circles of Dance: Hymns of the Satpanth Ismaili Muslim Saint Pir Shams (Albany: SUNY Press, 1995). 
Hindus in lower Sindh. ${ }^{5}$ It is unclear how closely welfare development coincided with Ismaili missionary activities. Nonetheless, Valliani reports that development attempts by missionaries bore fruit in the 196os with mass conversions among Bhils and Kohlis (10o of these were in Khebar). With conversion numbers increasing in Khebar, Ismailis established a jamatkhana in March $1976 .{ }^{6}$ The Ismailis associated with the jamatkhana subsequently formed the Khebar Welfare Committee and appealed to Shia Ismaili institutions for patronage. The committee also hired Alwaez Pir Bhai Haji (d. 1983), a senior Ismaili missionary. He gave religious and secular training to selected teenagers from the Khebar jamat (i.e., community) to become future missionaries. ${ }^{7}$ Alwaez Haji's training resulted in his students getting appointments by the Ismailia Association, the then equivalent to Ismaili Tariqah and Religious Education Board (ITREB).

Openness by Bhils and Kohlis to Ismailism can be a politically sensitive issue since the forced conversion of minorities in Pakistan has kindled national and international outrage in recent years. Schaflechner cites Human Rights Commission of Pakistan (HRCP) statistics documenting cases among Hindu girls from interior Sindh and southern Punjab. The H RCP and other NGOs estimate that twenty-five forced conversions occur monthly in Pakistan. ${ }^{8}$ If the case, it is imperative to delve into da'wahs' details, especially ones reported among disempowered communities like the Bhils and Kohlis who live under feudal conditions in interior Sindh.

While the earlier case of the Khojas involves a reaction to persecution by foreign invaders, post-Partition conversions in Khebar do not involve matters of external persecution. Poverty and greater socio-economic mobility are reasons for Bhil and Kohli openness to Ismaili missionaries. Nonetheless, due to a lack of data, such connections are frequently speculative. Alternatively, this article examines the Khebar Welfare Society and the socio-political Patel system as elements in conversion. I maintain that forces embedded in these two social contexts were catalysts in the work of Ismaili missionaries. The article has three main sections: The Patel and the Locals, The Missionaries, and Ismailia Khebar Welfare Society.

5 Amin Valliani, Modernization and Social Change: A Case Study of Ismaili Community of Pakistan, 1950-2010 (Karachi: Royal Book Company, 2012).

6 Ibid. The term jamatkhana is from Persian. It is the main space for religious and social gathering in some Muslim communities, like Ismailis and Sufis.

7 Alwaez is the title given to a missionary in the Ismaili community.

8 Jürgen Schaflechner, "Forced' Conversion and (Hindu) Women's Agency in Sindh," South Asia Chronicle 7 (2017): 4-5. 
In "The Limits of Cultural Hybridity: On Ritual Monsters, Poetic License, and Contested Postcolonial Purifications", Pnina Werbner writes about the "limits" of cultural hybridity. She states: "Far from denying the very possibility of critical consciousness, modernist anthropology afforded insight into how, in apparently closed societies, ritual performances and myths enacted ambivalences of power and paradoxes of sociality."

When addressing identity formation in society, it is wise to acknowledge individuals undergoing its processes. I was fortunate to work among individuals in Sindh who experienced identity shift. These individuals made sense of this process and rationalized it. I visited Mukhi Allah Dino's family in Khebar during my fieldwork (Figure 1). Mukhi Allah Dino became the first mukhi of jamatkhana in Khebar when established in $1976 .{ }^{10} \mathrm{He}$ was the son of Patel Dhannu (aka Patel Ali Muhammad), the first person in Khebar to embrace Islam and Ismailism. Mukhi Allah Dino reported that he was in his early thirties when Jan Muhammad (locally known as Bhagat Janu) came to his village. Despite being a Shia Ismaili Muslim, he chose to present himself as a Hindu Bhagat. ${ }^{11}$ It was due to Jan Muhammad that the da'wah found roots in Khebar. Mukhi Allah Dino's accounts are significant in this article, and they play a pivotal role in my research. I initially worked with him with the assistance of Alwaez Huzur Mukhi Muhammad Yousuf Nur Muhammad (aka Alwaez Muhammad Yousuf), the maternal great-grandson of Patel Dhannu.

When I asked locals, "Why did you choose to convert to Islam being Hindus?" many replied: "We were not Hindus."12 These replies were captivating

Pnina Werbner, "The Limits of Cultural Hybridity: On Ritual Monsters, Poetic License, and Contested Postcolonial Purifications,"Journal of the Royal Anthropological Institute 7.1 (2001): 134 .

10 Derived from the word "mukhya," the mukhi is the guardian of each jamatkhana. He is in charge of its management and internal affairs. The Mukhi is also the representative of the living Imam, the Aga Khan, and leads rituals at the jamatkhana.

11 Bhagat is a Hindu and Jain religious devotee who is a professional or unprofessional preacher and singer. Bhagat probably comes from baghti, the Sindhi term for both the performer and performance. Bhagat tradition no longer occurs in Sindh (Michel Boivin, The Sufi Paradigm and the Makings of a Vernacular Knowledge in Colonial India: The Case of Sindh, 1851-1929 [London: Palgrave-Macmillan, 2020], 273).

12 Because I struggle with terms like "convert," "converted," and "conversion," I have tried to do without them in this article. However, I have used them hesitantly. Since terms like "transformation," "transfiguration," "transmutation," and "regeneration" relate to "conversion," I struggle with using them too. In my view, all the terms simply imply degrees of identity in fluctuation. 


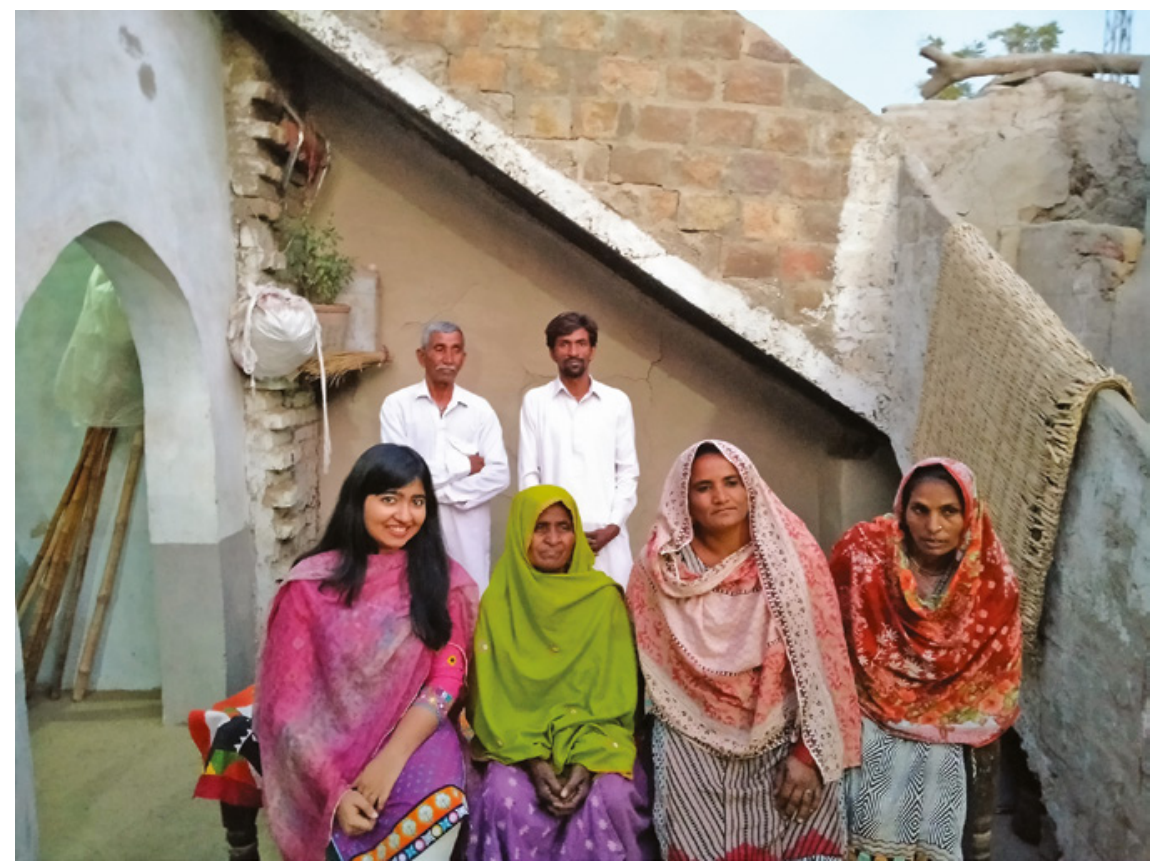

FIGURE 1 Interviewees and the author at Mukhi Allah Dino's home

because Kohlis and Bhils, two lower castes Hindu groups, were not comfortable self-identifying as Hindus. When I further probed, the answer was that "we belonged to a Hindu caste, but we had no religious inclination." Mukhi Allah Dino responded to the question in Sindhi with a smile:

We were dacoits (bandits) by profession. This jamatkhana in Khebar that you must have visited used to be a famous spot even before we became Ismailis because this used to be a repository where the dacoit community kept their riches and livestock plundered from nearby villages until they [i.e., the livestock] were sold for money in the market.

I had not known that the land for the jamatkhana got selected due to its value among dacoits. ${ }^{13}$ But it was an easy place for the missionaries to gather local people.

13 While Bhils and Kohlis struggled to sustain themselves through dacoity, it often did not pay because of counter-raids by others. To make a living, Bhils, and Kohlis also plowed wheat and banana fields for Muslim feudal lords, who were indignant toward them and reinforced their socio-economic isolation. 
Illiterate, Bhils and Kohlis in Khebar had never touched a Bhagavad Gita. The Vedas and other sacred texts were also only accessible to literate upperclass Hindus. Nonetheless, these groups held a "Hindu" worldview and Ismaili missionaries incorporated it into their teachings. Mukhi Allah Dino narrated Patel Dhannu's dialogues with Jan Muhammad. In these dialogues, the former confessed to living an "unscrupulous" life, which indicated a belief in repudiating a moral system. But it is interesting to note how people can express religious tendencies in not-so-religious ways. If a person denies having religious or ritualistic inclinations, they still carry social boundaries regarding "others." Mukhi Allah Dino with his family reported that being "low caste Hindus, we depended so much on Muslims." He also stated:

We were not religious people, but we were aware that Muslay [i.e., Muslims] belonged to a different world; they were self-sufficient. They were not from our community, and we didn't like them. We didn't even touch each other's food. They were the feudal lords.

From this statement, I reckoned the sense of honor that the Patel and his kin held within the community. If from a Patel lineage, one enjoyed authority over social, economic, and familial matters within the village. This feeling of superiority was evident when Jan Muhammad initially came to Patel Dhannu's house. Mukhi Allah Dino, his eldest son, was reluctant to serve him using personal kitchenware because he thought he did not match his status. Individuals in Khebar adhered to a hereditary Patel system. A Patel, now a diminishing authority, was the head of the village council, the governing body that traditionally decided daily life matters in the community. In this role, a Patel played a role in settling disputes. Even if a family in Khebar was not related to the Patel by blood, its members took his word as final. This fact helps illuminate why Jan Muhammad chose a Patel as a point for his first contact in Khebar - it was a latent method towards mass conversion.

Tazim Kassam raises questions about the Khojas' acculturation into Ismailism. She asks, "Did Satpanth exist before the ginans, or did it arise with the evolution of this sacred corpus?"14 There is a high probability that many Khojas were not conscious about getting called to a different religion. Instead, as Khan maintains, this process involved a reinterpretation of old ideals. She notes, regarding Nizari Ismaili missionary methods, that they used Hindu and Muslim terminology in tandem. This use was not a mishmash of the two

14 Kassam, Songs of Wisdom, 37. Satpanth is the name given to the spiritual path of the Khojas, and ginans refer to their sacred literature composed in vernacular languages. 
worldviews but aimed to offer a new lens to what individuals already adhered to; it was a reorientation of a conceptual framework. ${ }^{15}$ This position begs questions (like those Pnina Weber addresses) about how productive the idea of hybridity is for theorizing Bhil and Kohli conversions to Ismailism. Did da'wah involve a syncretic methodology like that previously employed by Nizari Ismaili missionaries? The answer that I reached via fieldwork in Khebar was yes.

Jan Muhammad met Patel Dhannu at a wedding in a nearby village named Mubarak Jarwar. ${ }^{16}$ Jan Muhammad treated him with so much dignity because he had heard from others that he was the Patel of Khebar. Patel Dhannu was impressed by his politeness, that coming from someone who lives a settled life in Hyderabad; something a resident of Khebar could only aspire to achieve. However, he was reluctant to befriend a Bhagat, what Jan Muhammad appeared to be. But Jan Muhammad developed a friendship through his amiable ways and intimated that he would someday come to visit him in Khebar. After three days, Patel Dhannu found him at his doorstep. Mukhi Allah Dino's niece, Ms. Habiba Qaim Ali, added that she knows from family accounts that Patel Dhannu's household was initially reluctant to let the stranger into their home. He could have been dacoit, and, even if he was a Bhagat, what did this family has to do with Bhagats? But Jan Muhammad had already convinced Patel Dhannu of his harmless character, so he let him in.

A fascinating point to note is that interviewees frequently used two terms: Hindukari and Dinkari. Hindukari was the word they used for religion before conversion, while they called their worldview after embracing Shia Ismaili Islam Dinkari. Din means faith, and kari means doing/practicing something. This distinction correlated to Mukhi Allah Dino and his family showing gratitude that this conversion episode occurred in their lives. Mukhi Allah Dino's wife raised both her hands as a sign of gratefulness and said to me that, "What would we have been doing if this had not happened! Our children would have been doomed in Hindukari!"

This conscious rejection was not unexpected. Building on Kassam and Khan's arguments about Khojas and missionary use of older ideas, I understood that Jan Muhammad gestured people toward a form of devotion and righteousness that they already understood (even if illiterate). Utilizing the Bhagavad Gita, Vedas, and bhajans, he and his wife invited individuals to a life of divine devotion. ${ }^{17}$ Even the jamatkhana, when first built in 1976 , was

\footnotetext{
15 Khan, 45-48.

16 Mubarak Jarwar is in Tando Allah Yar, Sindh.

17 Bhajans are Hindu devotional songs.
} 


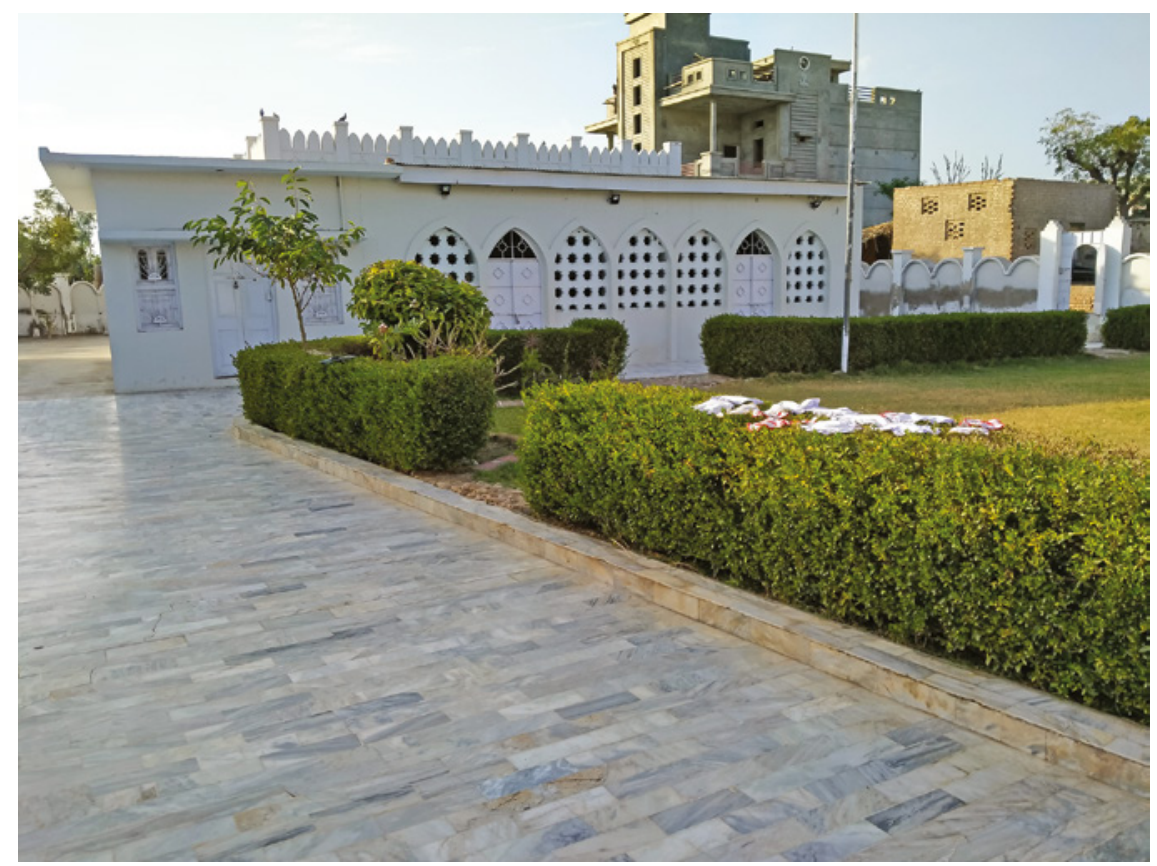

FIGURE 2 Khebar Jamatkhana (February 21, 2020)

called mandir (Figure 2). ${ }^{18}$ They did not offer individuals in Khebar a springboard shift. Instead, interviewees were comfortable narrating that it was only after a year and a half (and a considerable number of people following in the Patel's footsteps) that the dissemination tools of the Arabic dua (i.e., prayer) and a photo of Shah Karim Al-Husaini Hazir Imam (i.e., the 49th Imam of Shia Ismailis) got used. In the case of the Imam, he became represented as the longawaited dasa avatara. ${ }^{19}$

It was a challenge for me to accept this transition so easily at face value. I wanted to know how this identity shift proved favorable in communities that did not consider religion essential for their survival? I found two answers. The first was social rehabilitation. When Patel Dhannu's brothers first inquired about Jan Muhammad in his hometown, Kali Mori, in Hyderabad, they were confused about why a settled man was always returning to their village and teaching them religion for nothing. Jan Muhammad received them warmly and served them palla fish. This gesture was surprising. Muslims never ate with

18 Mandir is a Hindu temple.

19 Dasa Avatara (i.e., tenth avatar) relates to the Hindu belief that Vishnu reappears in ten different incarnations on earth. 
Hindus. This man and his wife were also pleasantly immersed in kachehri and treated them with hospitality. ${ }^{20}$ They were Muslims who did not hate them but wanted to support them. They saw this fact as a ladder to escape their social isolation and poverty.

Homi Bhaba's post-colonial thought on hybridity shows how people have difficulties conceiving mixed-descent groups. They remain "foreign," and society tags these groups as "problematic."21 I witnessed this fact in Khebar. Hindus hated Muslims and vice versa, but the two did not recognize how they borrowed practices from each other. For example, many Bhils and Kohlis had Muslim names, like Allah Dino and Yousuf. Even before Bhils and Kohlis converted to Islam, they strictly observed Muharram as a village holiday. (Villagers told me no farmer would even pick an ax to sharp it during this period.) In Sindhi, villagers used jarjalo or zilzilo, meaning earthquake, to describe how Imam Hussain, the grandson of Prophet Muhammad, was brutally assassinated at Karbala with his family and companions. Once during Muharram, Patel Dhannu and his five brothers traveled to Hyderabad to attend a Muharram procession. When there, they offered bay'ah to Mukhi Ghulam Hussain at the Prince Aly S. Khan Jamatkhana. ${ }^{22}$ A moulvi was called for the occasion to make them recite the kalima. ${ }^{23}$ The kamadiya (i.e., the mukhi's assistant) of the same jamatkhana organized a grand breakfast for these travelers. Mukhi Allah Dino reported:

As new Ismaili Muslims, we thought we were living a dream. There were wealthy influential Muslims here, including Jaffer Ali K. Mithani, Mukhi Sher Muhammad Nurani from Dambalo, Achar Shiko from Jhuddo, Mukhi Faiz Muhammad from Ghulab Laghari, among others, who were eating "with" us. They were more than welcoming.

This breakfast was also a key event for Bhils and Kohlis since they experienced a society where caste did not matter, and everyone could access the social ladder. "I am happy that it happened," answered Miss Nurjehan, wife of Alwaez Muhammad Yousuf, during an interview. She stated that the younger

\footnotetext{
$20 \quad$ Kachehri is the Sindhi word people use for a meeting place to gossip.

21 Satoshi Mizuthani, "Hybridity and History: A Critical Reflection on Homi K. Bhabha's Post-Historical Thought," Zinbun 41 (2008): 3 .

22 Bay'ah is an oath of allegiance to the Imam, primarily performed before his representative (i.e., a mukhi).

23 Moulvi is a doctor of Muslim law in South Asia. Kalima (i.e., stating that "Allah is One and Prophet Muhammad is His last Prophet") is a formal declaration for converting to Islam.
} 
generation of converts was now receiving an education - this fact brought on change that was only possible after becoming part of the Ismaili community.

Post-partition displacement among Sindhis has been a difficult chapter of South Asian history. In Pakistan, lower castes get ridiculed for having Islamic manners and disowned for belonging to a Hindu caste. As Boivin and Cook put it in a different context, locals frequently treated such groups with varying degrees of "sympathy, apprehension, and antagonism." ${ }^{24}$ After becoming Muslims, there were new sets of challenges. Like Shafique Virani, who addresses Guptis hiding their Muslim identity in Bhavnagar, India, there was fear among Bhils and Kohlis of becoming a social outcast within their community. However, economic issues and social rehabilitation were crucial concerns. ${ }^{25}$ Nevertheless, interviewees narrated unpleasant episodes of family dissociation, broken engagements (some of them on the very day of a wedding), and verbal or physical violence. Mr. Nurdin, a Police officer, posted in Khebar, recollected how people expected disagreements at the nikah (i.e., marriage) and circumcision ceremonies on account of conversions.

However, most in Khebar followed the example of the Patel. While some people reverted, others did not do so to their old Hindu identity. Some took on Sunni Muslim identities due to social pressure from people they traded with or professional colleagues. The present Patel of Khebar shared with me that being a first-generation Muslim meant being an outcast amongst Hindus and Sunni Muslims. The latter refused to accept them as Muslims since they were born into a stigmatized Hindu cast. He recalled an unpleasant episode when the Imam Sahab of the village mosque announced in his sermon not to eat with the Ismailis because they were not Muslims. ${ }^{26}$ Subsequently, Ismailis were not allowed at some dhabas. ${ }^{27}$ The Patel's family reported these facts to the village Station House Officer (i.e., a senior policeman). After the report, the Imam Sahab got punished, but Patel withdrew his case. He stated that the Imam is also our Muslim brother, never meant to hurt anyone, and "they expect that they won't be treated with discrimination in the future." As told by Mansoor Patel Ali, not all Sunni Muslims hated Ismaili converts. Some were so supportive

\footnotetext{
24 Michel Boivin and Matthew A. Cook, eds., Interpreting the Sindhi World: Essays on Society and History (Karachi and London: Oxford University Press, 2010), 11.

25 Shafique Virani, "Taqiyya and Identity in a South Asian Community," Journal of South Asian Studies 70.1 (2011): 99-139.

26 The Imam Sahab leads prayers in a Mosque and offers other community services like counseling.

27 Dhaba is a roadside food stall.
} 
that when Chandrat Majalis got held in nearby villages, Sunnis waited at the bus stop to convey donations to Ismailis who were departing for the occasion. ${ }^{28}$

\section{$3 \quad$ The Missionaries}

"On other occasions, they have worked without the institutional umbrella, out of their personal zeal and with a sense of service for the community," Valliani states about the missionaries who operated in Khebar. ${ }^{29}$ As part of the Shia Imami Ismaili Muslim community, I am familiar with its ethos of selfless service based on the Imam's blessings and community betterment. In my research, I could not reach any conclusion that suggests the missionaries undertook their work out of personal interests. In a conversation with Alwaez Madad Ali Karam Ali, Acting Assistant Director of Academic Affairs at ITRE B, I learned that those associated with the Ismailia Association (IA) received regular pay or "bakhshish." ${ }^{30}$ The IA didn't instruct individuals to undertake da'wah activities in lower Sindh in the twentieth century, but, instead, missionaries volunteered for the task. The missionaries working in nearby villages were aware of areligious worldviews among Bhils and Kohlis. They decided to extend social and religious support structures to them to improve their lives. While the IA did not institutionally sponsor this support, Alwaez Madad Ali reported they had the Imam's approval. Jan Muhammad, who got blessed by the 49th Imam, was the founder of these missionary and support activities in Khebar (as well as in Shah Ali and Alyabad).

Alwaez Muhammad Yousuf helped me interview a vital source, Rehmat Jan Muhammad (known as Rehmat Bai) from Kali Mori, Hyderabad. The second wife of Jan Muhammad, she accompanied her husband throughout his missions. According to Alwaez Muhammad Yousuf, who became Shia Ismaili Muslim in 1979 during the third da'wah cycle in Khebar, it was due to Jan Muhammad's "struggle and knowledge that we became Ismailis, but this struggle would have been incomplete without the magic of Rehmat Apa's voice." Rehmat Bai, a seventy-year-old lady at the time of our meeting, showed up with her daughter at IT REB, Hyderabad, and was more than happy to share her stories with me (Figure 3).

28 Chandrat Majlis/Majalis is a religious gathering celebrated by Shia Ismaili Muslims.

29 Valliani, 5 o.

30 Ismailia Association is the older name for the Ismaili Tariqah and Religious Education Board (ITREB) and the institution supervising the tariqah and religio-academic matters of the community. 


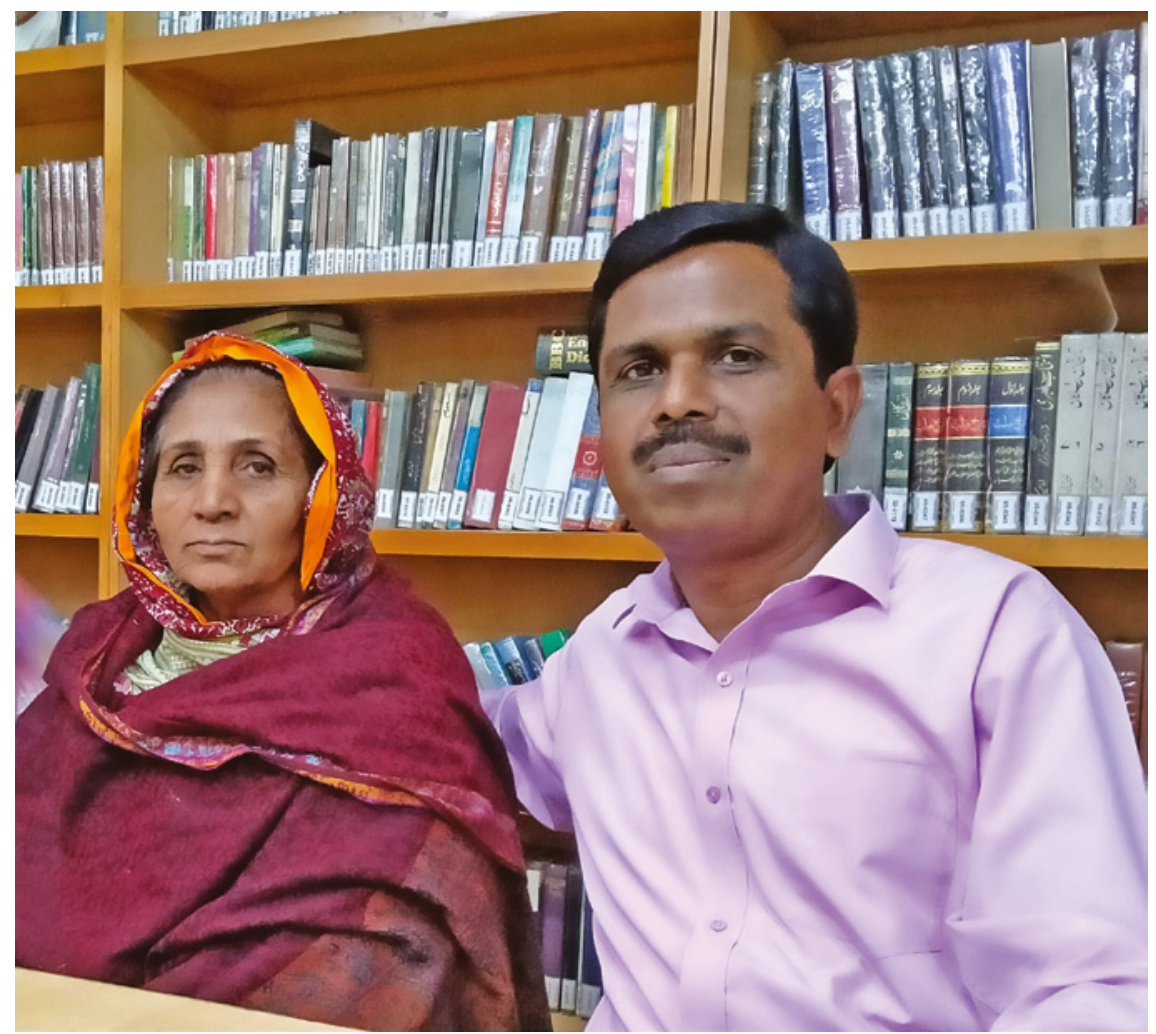

FIGURE 3 Alwaez Muhammad Yousuf posing with Rehmat Bai at the ITRE B Office, Hyderabad

Imam Sultan Muhammad Shah (d.1957) approved Bhagat Pirbhai (d. 1973) and Wazir Ali Muhammad Daya (d. unknown) for missionary work in Gujarat and other parts of India in 1952. In 1955, Jeeva Bhai, from Tando Bhago, District Badin, became Ismaili in one such da'wah cycle. The missionaries renamed Jeeva Bhai when he became a Shia Ismaili Muslim. ${ }^{31}$ Jan Muhammad later got married to a woman from his village. But he married for a second time around forty to forty-five to a younger girl named Rehmat. This second wife, whom I met with, did not have children until after six years of marriage. As a result, she accompanied her husband on his missionary work. Rehmat Bai's narrative was quite like what I heard about Jan Muhammad from converts: he initially entered the Patel's house and won influential converts, including the Patel and

31 Like bhagats, he was well-versed in both Hindu and Muslim devotional literature and different South Asian languages. 
his five brothers. Subsequently, and gradually, this process expanded over the whole village and numbered up to 1,500 converts over two years.

Jan Muhammad was a reciter and scholar of ginans and bhajans, and he tutored his wife in both. In 1964, when the 49th Imam of Shia Imami Ismaili Muslims came to Hyderabad for didar, he went to the Imam at a mehmani with this ardent desire to continue Bhagat Pirbhai's missionary work. When the Imam patted his shoulder, he received it as a sign of approval and subsequently approached the Patel of Khebar. ${ }^{32}$ At first, he showed up as a vagabond, sleeping outside the Patel's house. Thinking he was a wandering bhagat, the Patel asked his wife to treat him with food and water every two to three days. "He was not mazhabi (i.e., religious), but he was nice to others," Rehmat Bai commented about Ali Muhammad Patel. When the Patel and his family inquired about Jan Muhammad, he said he lived in Hyderabad. Afterward, the Patel with his brothers visited Kali Mori, Hyderabad. After asking around, they arrived at Jan Muhammad's home and discovered that the "bhagat" lived a decent life with his family. Here the Patel met Rehmat Bai, then a fifteen-year-old girl (who reminded him of Sohni, his daughter who had recently passed away at about the same age). From that day on, Rehmat Bai accompanied her husband on his visits to Khebar and attracted listeners to her melodious bhajan singing voice.

Virani's arguments about how, for the Guptis of Bhavnagar, taqiyya (i.e., dissimulation) is "not simply a veil used to avoid harmful consequences but forms an integral part of the Guptis' belief system and identity" relates to the Khebar case. In Rehmat Bai's view, bhajans were not alternatives to ginans. Bhajans entail a messianic framework in which Hindus wait for the dasa avatara. Ginans, on the other hand, are naturally responsive to bhajans, which showcase Mawla Ali as the dasa avatara. Alwaez Muhammad Yousuf also recollected how Rehmat Bai and Jan Muhammad recited bhajans and then ginans as responses. The implication was that the Lord they are searching for through bhajans has reincarnated as Mawla Ali in the ginans. ${ }^{33}$

1964 was an important year. It was the 49th Imam's visit to Pakistan. Since private missionary activities operated in lower Sindh before this visit, there were people from Hindu castes who, even without reciting kalima and officially becoming Muslims, traveled to Hyderabad to see and attend the didar. Jan Muhammad was directly involved in taking a group of Hindus with him

32 Didar is an official congregation that occurs when the Imam visits a jamat. Mehmani is an offering made to the Imam by an individual or a family.

33 An example is "Saheb kesa hai" (What is your Lord like?). Then in response, the recited ginan (most likely a garbi [i.e., a traditional Gujarati folk song] or venti [a supplicative genre in devotional literature]), "Saheb ji tun more man bhave" (My Lord! You are dear to my heart), which then continued to "Chalo saheli var jova jai-e; so piyaa mene paya" (Come friends! Let us go in the quest of the Lord. Oh! I have found that very Lord). 


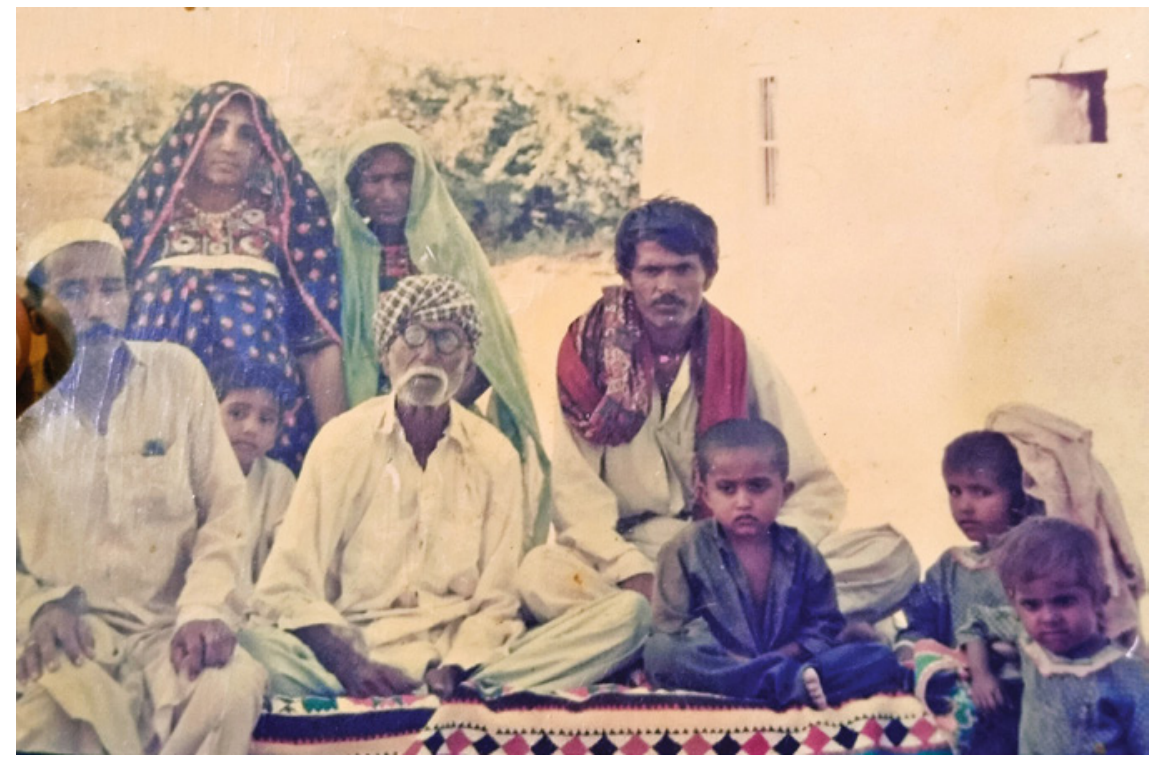

FIGURE 4 Jan Muhammad (first from the left in the front) and Rehmat Bai (first from left at the rear) with a new Ismaili family in Khebar

to the didar, without informing the larger Ismaili Council, "so that they see that this is the true faith." After attending didar, many Hindus returned to their villages and announced to others that they had seen the dasa avatara. Didar was an impetus. Hindus of Khebar started paying homage to photos of the 49th Shia Ismaili Imam's photo but called it a depiction of Rama or Krishna. Gradually, these photos found places inside many homes, and people started to believe that the dasa avatara had manifested. They publicly stated that they would remain Hindus but that the missionaries would make them "good Hindus" because both Bhils and Kohlis disliked Muslims. "I remember a bunch of Kohlis asking us: You are not here to make us Muslay, and we assured them that we are not," Rehmat Bai stated (Figure 4).

From 1964 to 1967 , da'wah was a clandestine affair, and missionaries used the terminologies of Hinduism to develop greater religious inclination among Bhils and Kohlis. They reinterpreted Hinduism, like Khan argued was the case for Khojas. Hindu beliefs, myths, and symbols were not simply adopted. Instead, missionaries created new functionalities for existing signs. Regarding this process, Khan draws an apt analogy of a time machine:

More than that, the Nizari missionaries literally infiltrate the theatre of Hindu mythology, just as science fiction characters penetrate, with the help of a time-machine, into the realm of the past and even take part in 
historical events by which they attempt to modify the course of history. In this way, one could say that Nizari poets have not negated, but partially "rewritten" and recast into a new mold the epics and legends associated with Hinduism. ${ }^{34}$

Bhajans posited the dasa avatara as Naklanki (i.e., the immaculate or faultless one). But missionaries transformed Naklanki into a reference for Imam Ali and used it with the Arabic epithet masum, a term frequently used for Ismaili Imams. The promises of liberation (i.e., moksha) and paradise (i.e., swarg, amrapuri, or vaikunth) got redirected to the soteriological potential of the Imam. As mentioned previously, the mud-built jamatkhana made by missionaries was a mandir for housing the Gita and Vedas at its outset. At first, a zikr for Ram occurred, and then, gradually, Ali got incanted in that space. ${ }^{35}$ Missionaries recited the Arabic dua in a shallow voice initially, but those attending chanted "Ram" and "Krishna." In 1967, when the community was more extensive, individuals chanted formally in unison. Such behavior is not unique. Teena Purohit, like Khan, comments on how Ismailis cannot be easily understood as a "sect" or an "addendum" to the grand Middle Eastern Islamic narrative because their beliefs transpire within a culturally hybrid Indo-Islamic ecumene. ${ }^{36}$

When I asked Rehmat Bai if any other da'wah tools proved effective in the conversion process, she made two points. One was language. The portion of Sindh where da'wah activities took place had two parts: Lar and Tharparkar. Lar is a "mainstream" area that constitutes populated regions, like Badin, Tando Bhago, and Tando Turail. This area predominantly speaks the Sindhi dialect of Lari. In contrast, people in Khebar predominantly use the Tharparkar dialect. Rehmat Bai said she was not used to it, but her husband knew it quite well and taught her. The absence of a language barrier meant there were high chances of success. She also said her husband was quite meticulous about not appearing "foreign." She showed me photographs of herself dressed in a Tharparkar costume (Figure 5) - an embroidered ghagra (i.e., a skirt) with her head covered until the forehead. Sometimes, she wore white bangles on her arms because she was married (unmarried women cover up to their elbows). The second tool she pointed to was intellectual debate. She said that her husband had good interfaith knowledge. He was an excellent orator who always

\footnotetext{
34 Khan, 48-49.

35 Zikr is a verbal remembrance or remembrance by heart. It is a primary ritual among Ismailis as well as Sufis.

36 Teena Purohit, "Reading Global Islam through Messianic Renewal in Dasa Avatar,"Sikh Formations 3.2 (2007): 151 .
} 


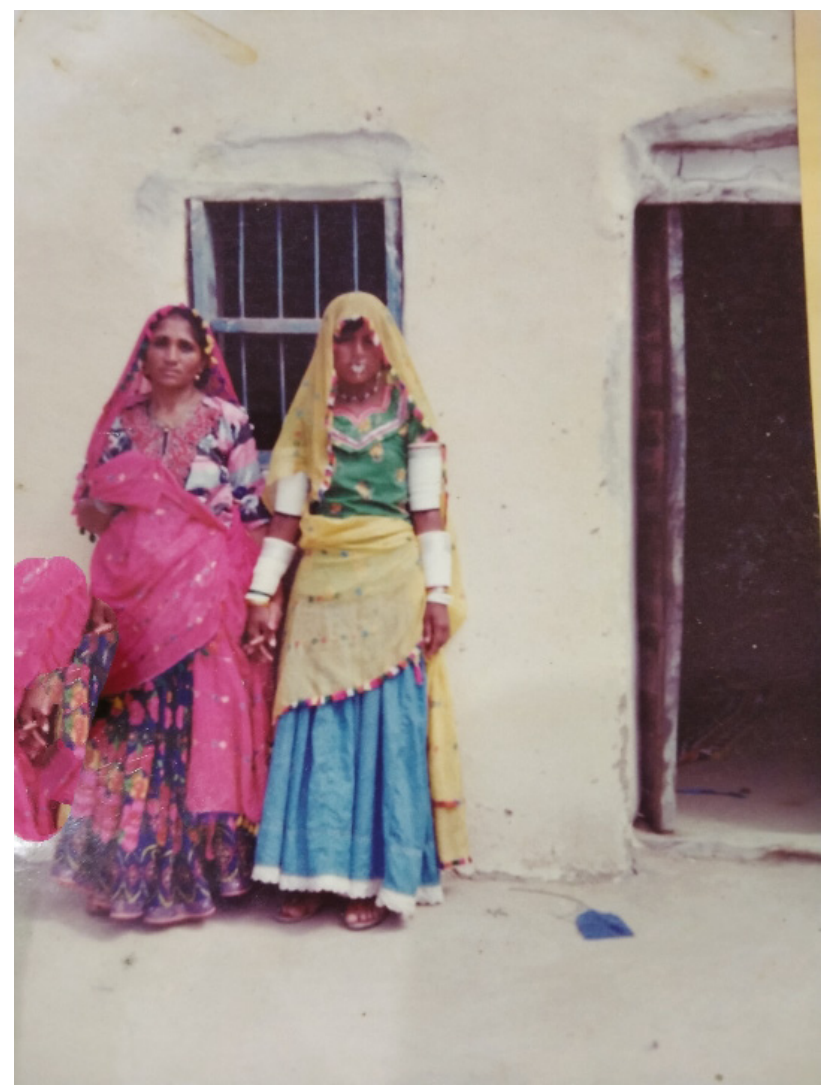

FIGURE 5 Rehmat Bai (left) dressed in Tharparkar style clothing

attracted many people. She credited Jan Muhammad's argument, analysis, and delivery of ideas with expanding the number of converts in Khebar.

As far as I could find, Rehmat Bai is the only living missionary from the first da'wah group because she was young at its time. If there were other living missionaries from that group, they were not accessible to interview. Despite only interviewing Rehmat Bai, she was an incredible resource. But there was a group of missionaries involved in the conversion process. Due to Alwaez Muhammad Yousuf's writings, I learned that Alwaez Haji Pir Muhammad, Alijah Abdul Aziz Rai Abdullah Heerji, and Alwaez Mustafa Mansoor Ali were also part of the group. ${ }^{37}$ In addition to these individuals, influential leaders operating from

37 Alijah and Rai are both titles bestowed to individuals by Imam for being in service to the Imam and his jamat for a specific period of time. 
the Khebar Welfare Society were important. This organization and these individuals are the focus of this article's next section.

\section{The Khebar Welfare Society}

Before conversion by Ismaili missionaries, there was a sense of community among Bhils and Kohlis in Khebar at an imaginative, if not a functional level. They had a distinct historical narrative that influenced their social standing. It was essential to reconstruct their sense of themselves to make them part of the Ismaili community. This reconstruction had a socio-economic element and was not merely religious. Although never formally institutionalized, the critical social organization in this process was the Ismailia Khebar Welfare Society (commonly referred to as the Khebar Welfare Society) and its liaison with Shia Imami Ismaili Council for Pakistan.

My understanding of the Khebar Welfare Society comes from interviewing Alwaez Madad Ali Karam Ali and Alwaez Muhammad Yousuf's writings. The latter's writings document a discussion between Wazir Qasim Ali Muhammad Jaffer (President of IA) and the society. Unlike groups patronized by the state and powerful international agencies, the Khebar Welfare Society never received official financial patronage. There were also no sources indicating that Ismaili missionaries engaged in violence. In fact, in all the narratives that I collected, none involved the radicalization of religious ideals and aspirations. As the Khebar Welfare Society's name suggests, the group operated privately to support underprivileged groups in lower Sindh through welfare efforts. It was not a formal organization initially. Its funding was often personally contributed by influential leaders and missionaries. But, sometimes, there was support from the Shia Imami Ismaili Council for Pakistan. This support is how the Khebar Welfare Society first came to be known more broadly when, in the early 196os, the council marked funding for Khebar, Shah Ali, and Alyabad. The society's welfare initiatives were not utterly aloof from exposing people to religious ideas, but neither did its activities explicitly include religious preaching. The organization held faith-based and socio-economic elements in a composite or "an interplay between historical dynamics and social factors." 38

During the first, second, and third cycles of da'wah, the Khebar Welfare Society operated well in the field and helped rehabilitate converts. The society

38 Michel Boivin, "Sufism, Hinduism, and Social Organization in Sindh: The Forgotten Tradition of Pithoro Pir," in Interpreting the Sindhi World: Essays on Society and History, eds. Michel Boivin and Matthew A. Cook (Karachi and London: Oxford University Press, 2010), 117. 
even developed settlements in Hyderabad and Karachi. The most noteworthy individuals working for the Khebar Welfare Society were Jan Muhammad, Patel Ali Muhammad Sukhio (from Khebar), Mukhi Sher Muhammad Nurani (from Dambalo), Mukhi Jaffer Ali K. Mithani and Dost Muhammad (from Banbhore), Mukhi Ghulam Haider Muhammad Juman (from Dasori), Muhammad Juman (from Sheikh Bhirkio), and Nur Ali Qaim (Gwadri).One of the many vital roles of the Khebar Welfare Society was as a linchpin. It represented the Khebar jamat at the axis of official institutions. Alwaez Muhammad Yousuf pointed out how the Khebar Welfare Society introduced the Khebar jamat to the larger Ismaili community. In 1979, Mukhi Jaffer Ali K. Mithani, representing the Khebar Welfare Society, and Wazir Ramzan Merchant and Wazir Akbar Ali H. Karamali met with His Highness Prince Karim Aga Khan, the 49th Imam of Shia Ismaili Muslim community at the Aiglemont estate near Paris. In this meeting, along with other concerns, they submitted a special request to the Imam that friends and relatives of new Khebar jamat desired to be a part of the community. Their request got granted because they agreed to take responsibility for the group's quality of life and plans for good health and education. In March 1979, the IA arranged a kalima ceremony in Karachi, where a mufti led a ceremony to change Hindu names to Muslim names. ${ }^{39}$ Alwaez Yousuf shared that his name was Yousuf before embracing Islam, so the mufti asked him if he wanted to continue with his old name as it was already a Muslim name. He added Muhammad to his name, and he was Muhammad Yousuf afterward. A few days later, a bay'ah ceremony took place at the Kharadar Jamatkhana in Karachi. A taliqa from the Imam arrived on October 9, 1979, that expressed acceptance of the new Ismailis from Khebar into the Shia Ismaili Muslim community and conveying to them affectionate blessings. ${ }^{40}$

In November 1979, the 49th Imam came to Pakistan for a visit. The Ismaili community arranged a mehmani, and representatives from the Khebar Welfare Society presented offerings at it. While accepting the offerings, the Imam entrusted Huzur Mukhi Patel Ali Muhammad to strengthen the younger generations in religious education..$^{41}$ After returning from mehmani, Patel Ali Muhammad conveyed the Imam's instruction to others at the Khebar Welfare Society. Afterward, it selected adolescent boys from the villages in which the society operated to prepare a group of fifteen to twenty to receive waezin training in Karachi. ${ }^{42}$ Musa Bhai Mithai Wala, a member of the Khebar

39 A mufti is a Muslim legal expert empowered to give rulings on religious matters.

40 Taliqa is an official letter from the Imam of the time to his jamat. I got a photocopy of this taliqa through Alwaez Muhammad Yousuf.

41 Huzur Mukhi is the title given by the Imam to individuals for being in service to him and the jamat for a specific period of time.

Waezin are missionaries. 


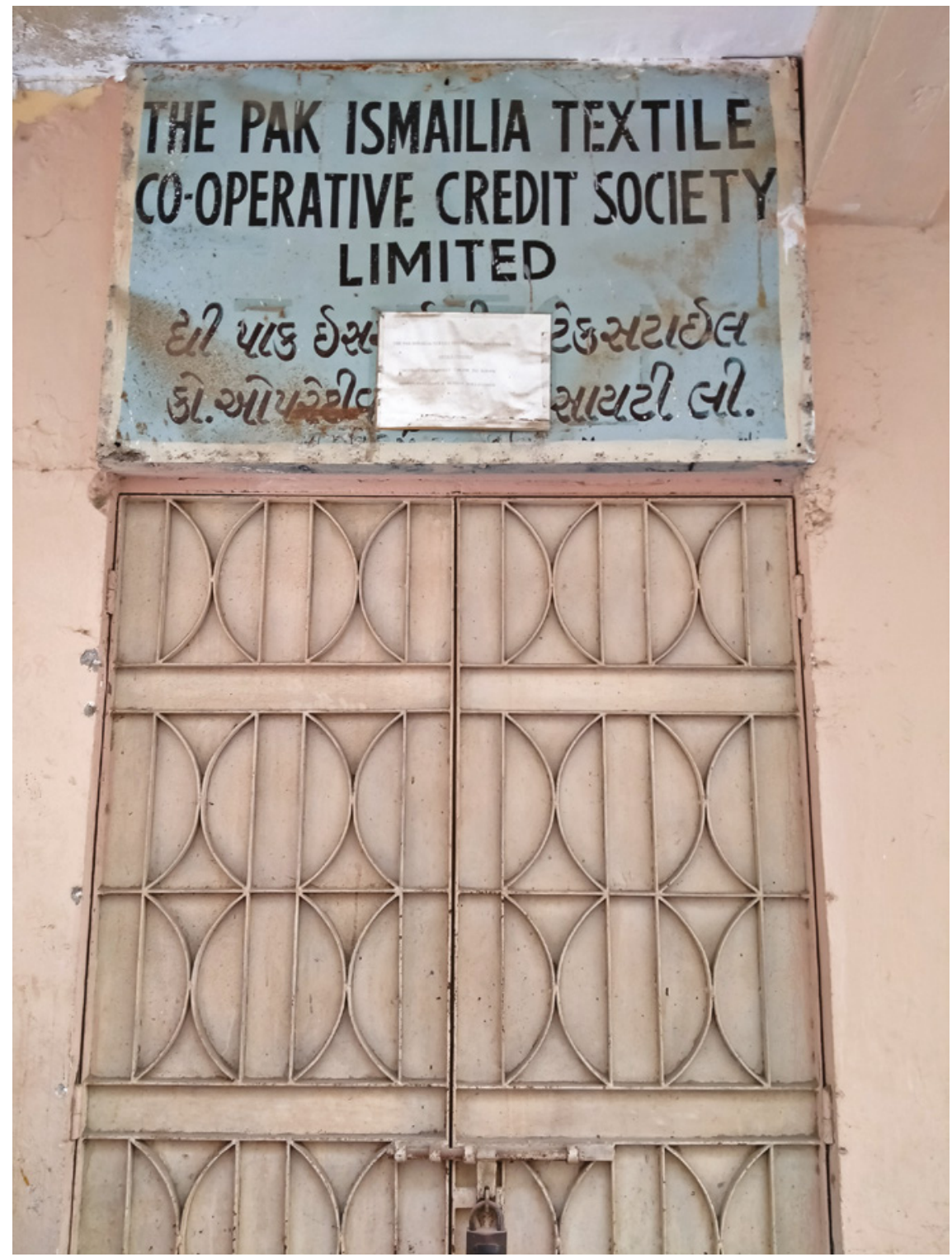

FIGURE 6 The gate of Khebar Welfare Society's property in Karachi donated by Moosa Bhai Mithai Wala

Welfare Society who ran a sweets business in Karachi, donated a flat where the boys could live and pursue their secular and religious studies (Figure 6). At first, the boys' families were reluctant to send them because they could earn by working in the fields. The Khebar Welfare Society offered them stipends larger than their annual income to compensate the boys' families. Alwaez Haji 
Pir Muhammad, learned in Quran, Hadith, Sirah, Shi'i studies, philosophy, and logic, became a full-time tutor. Alijah Abdul Aziz Rai Abdullah Hirji and Alwaez Mustafa Mansoor Ali were also involved. The boys grew into full-time missionaries, which the ITRE B later hired. Among the boys trained as missionaries in the first cycle were Alwaez Karim Baksh Khaliqdina and Alwaez Abdul Rehman Fateh Ali of the Khebar jamat.

Alwaez Muhammad Yousuf and Alwaez Pyar Ali Ghulam Haider are two similar missionaries that I know in my capacity as a community member. I attended sessions and read writings by both individuals. According to Alwaez Muhammad Yousuf:

We couldn't hold a pencil before that. I was around thirteen at that time, like other boys in the group, and we only memorized waez scripts by rote learning that Alwaez Haji Pir Muhammad prepared for us. But we worked hard. The committee and our teachers worked hard. At fourteen, an urban lad appears for board exams because he had been schooled for at least ten or eleven years before that. We were new to writing, yet we appeared for the secular examination after three-four years. Today, most of the waezin from this group have master's degrees in more than one discipline, and they are excellent at Urdu, English, Sindhi, and Arabic.

The role of the Ismailia Khebar Welfare Society was tremendous in bringing these results. The waezin under training got opportunities to deliver sermons before jamat and the jamati leadership.

Alwaez Madad Ali Karam Ali reported that Shia Imami Ismaili Council now institutionalizes most funding and officially addresses socio-economic concerns in the community. Nevertheless, the Khebar Welfare Society remains indispensable. As discussed earlier, it bridged the gap between the new Ismaili group in Khebar and other jamati institutions. In 2000, when the Imam visited Pakistan, the council took responsibility for disseminating didar tokens within the jamat. It strictly monitored the process, and the occasion remained a community affair. When it came to the Khebar jamat, regional ITREB was reluctant to issue cards to these individuals because much happened privately; the institutions did not have access to demographic records from the region. Alwaez Madad Ali Karam Ali of the IтREв presented a report that stated they were essentially a part of the community by their own will. He said to the ITREB management that a large portion of the Khebar jamat is Shia Imami Ismaili Muslim by belief, so there is no reason for not letting them become a part of the congregation. 


\section{$5 \quad$ Conclusion}

What role did the Patel system, missionaries, and the Khebar Welfare Society play in converting Bhils and Kohlis? This question is about power. Missionaries and the Khebar Welfare Society largely managed the process. But my goal was to ask whether such external entities deserved sole credit for the successes of conversion? What roles did the Patel system and local individuals play in the process? Was conversion culturally and conceptually configured in ways that made people fertile to external influences, or was it an organic shift?

I conclude that it was organic. External influences were crucial variables in Khebar, but they would not have been successful without a favorable preexisting conceptual framework. Khan notes that Ismailism and Hinduism share flexible traits, a significant insight for my research. Khojas realigned their identities to Islam and had an adaptable approach toward religion that did not depend on a single set of practices. Like Hinduism, Ismailism has an open-mindedness capacity that permits it to survive in societies that are in transition. In this sense, conversion from Hinduism to Ismailism does not necessarily represent a radical socio-cultural shift. This shift also involved crucial matters of social rehabilitation. The social upliftment opportunities that Ismailism offered to Bhils and Kohlis were significant. As a result, rather than transcending forces controlling the conversion process externally, its dynamics operated organically on a fertile socio-cultural and historical plain of missionaries, Patels, and individuals associated with the Khebar Welfare Society. 